\title{
Effects of pH on Biomass, Maximum Specific Growth Rate and Extracellular Enzyme Production by Three Species of Cutaneous Propionibacteria Grown in Continuous Culture
}

\author{
By J. GREENMAN ${ }^{1} \dagger$ K. T. HOLLAND ${ }^{1 *}$ AND W. J. CUNLIFFE ${ }^{2}$ \\ ${ }^{1}$ Department of Microbiology, Leeds University, Leeds, U.K. \\ ${ }^{2}$ Departments of Dermatology, The General Infirmary and St. James's (University) Hospital, \\ Leeds, U.K.
}

(Received 18 June 1982; revised 18 November 1982)

\begin{abstract}
Three cutaneous propionibacteria, Propionibacterium acnes, Propionibacterium avidum and Propionibacterium granulosum, were grown in chemostats using semi-synthetic medium at various $\mathrm{pH}$ values. Growth occurred between $\mathrm{pH} 4.5$ and 7.5 for $P$. acnes and $\mathrm{pH} 5.0$ and 8.0 for $P$. avidum and $P$. granulosum. The highest $\mu_{\max }$ was at $\mathrm{pH} 6.0$ for the three species. Maximum biomass production was obtained at $\mathrm{pH} 6.0$ for $P$. acnes and $P$. avidum and at $\mathrm{pH} 7.5$ for $P$. granulosum. Extracellular enzyme production occurred over the entire $\mathrm{pH}$ growth range when denaturation of the enzymes was taken into account. However, detectable activity of the enzymes was found in a narrower range of $\mathrm{pH}$ due to the denaturation of the enzymes at low or high $\mathrm{pH}$ values. The highest production of enzymes occurred at $\mathrm{pH}$ values between 5.0 and 6.0 , apart from the production of hyaluronate lyase of $P$. granulosum (pH 6.0 to 7.0) and the proteinase of $P$. acnes and $P$. avidum (pH 5.0 to 7.5). Propionibacterium acnes produced a lipase, hyaluronate lyase, phosphatase and proteinase activity. Propionibacterium avidum produced a lipase and proteinase activity. Propionibacterium granulosum produced a lipase and hyaluronate lyase.
\end{abstract}

\section{INTRODUCTION}

Propionibacterium acnes, Propionibacterium avidum and Propionibacterium granulosum are inhabitants of normal sebaceous follicles of human skin (McGinley et al., 1978). Propionibacterium acnes and $P$. granulosum are found in acne lesions (Marples et al., 1973: Leyden et al., 1975; Gloor \& Franke, 1978). Holland et al. (1978) hypothesized that microenvironmental changes in sebaceous follicles are major factors in determining the physiology of the bacterial inhabitants with consequent effects on the follicle. $\mathrm{pH}$ would be an important variable in this environment.

Cutaneous propionibacteria produce extracellular enzymes including lipase (Hassing, 1971; Kellum et al., 1970; Ingham et al., 1981; Greenman et al., 1981), hyaluronidase (hyaluronate lyase) (Puhvel \& Reisner, 1972; Ingham et al., 1979; Greenman et al., 1981), proteinase, DNAase (Marples \& McGinley, 1974) and acid phosphatase (Ingham et al., 1980; Greenman et al., 1981), which may play a role in the initiation of inflammation in acne (Holland et al., 1981).

The aim of this comparative investigation was to determine the effect of changing the $\mathrm{pH}$ on the physiology of $P$. acnes, $P$. avidum and $P$. granulosum grown in chemostat cultures and of particular interest was extracellular enzyme production.

\section{METHODS}

Organisms and media. Propionibacterium acnes (laboratory strain P37), P. avidum [laboratory strain PF77(i)] and $P$. granulosum [laboratory strain PF208(ii)] were isolated, identified and maintained as described by Greenman $e t$ al. (1981).

$\dagger$ Present address: Department of Science, Bristol Polytechnic, Bristol, U.K. 
Table 1. Dilution rates used in wash-out experiments to determine the maximum specific growth rates of $P$. acnes, $P$. avidum and $P$. granulosum

Maximum specific growth rate, $\mu_{\max }\left(\mathrm{h}^{-1}\right)$ of:

\begin{tabular}{|c|c|c|c|}
\hline $\mathrm{pH}$ & P. acnes & P. avidum & P. granulosum \\
\hline $4 \cdot 5$ & $0 \cdot 23$ & - & $-\ldots$ \\
\hline $5 \cdot 0$ & 0.29 & $0 \cdot 28$ & $0 \cdot 24$ \\
\hline $5 \cdot 5$ & $0 \cdot 25$ & $0 \cdot 28$ & $0 \cdot 21$ \\
\hline $6 \cdot 0$ & $0 \cdot 26$ & $0 \cdot 28$ & $0 \cdot 23$ \\
\hline $6 \cdot 5$ & $0 \cdot 23$ & 0.23 & $0 \cdot 23$ \\
\hline $7 \cdot 0$ & $0 \cdot 24$ & $0 \cdot 24$ & $0 \cdot 24$ \\
\hline $7 \cdot 5$ & $0 \cdot 28$ & 0.29 & $0 \cdot 29$ \\
\hline $8 \cdot 0$ & - & 0.27 & $0 \cdot 18$ \\
\hline
\end{tabular}

Table 2. Denaturation constants (ג) for the extracellular enzymes of P. acnes, P. avidum and $P$. granulosum at different $\mathrm{pH}$ values

The denaturation constant was zero for proteinase of $P$. acnes and $P$. avidum at all $\mathrm{pH}$ values.

Denaturation constant, $\lambda\left(\mathrm{h}^{-1}\right)^{*}$

\begin{tabular}{ccccccc} 
Lipase & $\begin{array}{c}\text { Hyaluronate } \\
\text { lyase }\end{array}$ & Phosphatase & Lipase & & \multicolumn{2}{c}{$\begin{array}{c}\text { Hyaluronate } \\
\text { lyase }\end{array}$} \\
4.5 & $\overbrace{0.51}^{P . \text { acnes }}$ & 0.244 & 0.015 & 0.116 & 0.056 & 0.06 \\
5.0 & 0.35 & 0.14 & 0.004 & 0.09 & 0.057 & 0.04 \\
5.5 & 0.09 & 0.005 & 0.064 & 0.03 & 0.03 & 0.003 \\
6.0 & 0.33 & 0.034 & 0.16 & 0.116 & 0.02 & 0.005 \\
6.5 & 0.64 & 0.315 & 0.42 & 0.48 & 0.02 & 0.038 \\
7.0 & 1.56 & 0.420 & 0.46 & 0.56 & 0.105 & 0.64 \\
7.5 & 3.52 & 1.4 & 0.81 & 0.94 & 0.15 & 0.73
\end{tabular}

* For methods of calculating $\lambda$, see Eaves et al. (1979).

The medium was that used by Eaves et al. (1979). In addition, sterile glucose solution $(10 \%, w / v)$ was added aseptically to a final concentration of $0.2 \%(\mathrm{w} / \mathrm{v})$ for $P$. granulosum, which requires glucose for good growth (Greenman et al., 1981).

Continuous culture apparatus and conditions. Organisms were grown in a one litre culture vessel with control modules for temperature, $\mathrm{pH}$, gas flow and stirrer rate (Series 500, L.H. Engineering, Stoke Poges, Buckinghamshire). The growth conditions were those used by Eaves et al. (1979). The $\mathrm{pH}$ was preselected and maintained at a constant level ( \pm 0.1 unit) over the range $\mathrm{pH} 4.0$ to 8.5 in 0.5 unit increments by the automatic addition of $2 \mathrm{M}-\mathrm{NaOH}$ or $2 \mathrm{M}-\mathrm{HCl}$. Dilution rates were set to allow a specific growth rate of $0.33 \mu_{\max }$ for each particular $\mathrm{pH}$ condition used.

Determination of biomass and maximum specific growth rates. These were determined as described by Greenman et al. (1981). The dilution rates used for washout are given in Table 1. Production rate of biomass was expressed as g dry wt cells $\mathrm{l}^{-1} \mathrm{~h}^{-1}$

Extracellular enzymes. Lipase (EC 3.1.1.3), hyaluronate lyase (EC 4.2.2.1) and acid phosphatase (EC 3.1.3.2) activities were assayed by the methods used by Holland et al. (1979). Proteinase activity was assayed by the method of Millet (1970). All activities were expressed as $\mu$ mol end-product $\mathrm{h}^{-1}\left(\mathrm{mg}\right.$ dry wt cells) ${ }^{-1}$ apart from the proteinase activity, which was expressed as units $\mathrm{h}^{-1}$ (mg dry wt cells) $)^{-1}$, where a unit is defined as $\left(A_{440} \times\right.$ $100) /(T \times 0.5)$ and $T$ is the time of incubation of the assay mixture. Production rate $\left(\mathrm{h}^{-1}\right)$ of this enzyme was expressed as units $\mathrm{h}^{-1}$ (mg dry wt cells) $)^{-1}$.

Production rate of the other extracellular enzyme activities was expressed as $\mu$ mol end-product $\mathrm{h}^{-1}$ ( $\mathrm{mg} \mathrm{dry} \mathrm{wt}$ cells $)^{-1} \mathrm{~h}^{-1}$. The extracellular enzymes had different stabilities at different $\mathrm{pH}$ values. The corrected production rates were calculated from the measured activities using a correction formula $(\lambda+D)$ measured activity/D, where $D$ is the dilution rate and $\lambda$ is the denaturation constant for the enzyme at a given pH (Eaves et al., 1979). The denaturation constants are given in Table 2. Proteinase was stable under the conditions tested and no correction had to be made.

Steady state. Biomass and extracellular enzyme activities were determined on samples taken from the chemostat during the particular conditions of $\mathrm{pH}$ that were selected. Only after a minimum of six culture volume changes had occurred between particular conditions was a steady state condition considered to be achieved. 
Statistical analysis. Linear regression analysis was used to determine the slope of the curve for the wash-out data for calculation of $\mu_{\max }$.

For biomass and extracellular enzyme production data the standard error of the mean was computed and, with the number of samples the $\pm 95 \%$ confidence limits were calculated.

\section{RESULTS}

Cell biomass and extracellular enzyme production were measured for each species of Propionibacterium grown at a steady state, with the $\mathrm{pH}$ of the growth medium increased from $\mathrm{pH} 4.0$ to 8.5 in 0.5 unit increments. All steady states were at $0.33 \mu_{\max }$ for the particular $\mathrm{pH}$ and organism studied. This enabled comparison of the performance of the three species at different pH values (Evans, 1976; Herbert, 1976; Tempest, 1976).

\section{Maximum specific growth rates}

The results for $\mu_{\max }$ are shown in Fig. 1. Propionibacterium avidum and $P$. granulosum grew within the same $\mathrm{pH}$ range ( $\mathrm{pH} 5.0$ to 8.0 ), whilst $P$. acnes grew within the range $\mathrm{pH} 4.5$ to 7.5 . The curves show a broad optimum $\mathrm{pH}$ range for the three species with the highest values of $\mu_{\max }$ $\left(0.23 \mathrm{~h}^{-1}\right.$ for $P$. acnes $; 0.21 \mathrm{~h}^{-1}$ for $P$. avidum $; 0.15 \mathrm{~h}^{-1}$ for $P$. granulosum $)$ recorded at $\mathrm{pH} 6.0$.

\section{Biomass production}

Propionibacterium acnes and $P$. avidum behave similarly with optimum production of biomass at $\mathrm{pH} 6.0$ (Fig. 2). In contrast, $P$. granulosum shows maximum biomass production at $\mathrm{pH} 7.0$ to $7 \cdot 5$. Biomass production increases steadily up to $\mathrm{pH} 7.0$ and after 7.5 rapidly decreases to zero.

\section{Extracellular enzyme production}

The production of extracellular enzyme was determined from enzyme activity in the culture supernatant and the dilution rate used. Detailed results for $P$. acnes are shown in Figs 3 to 5 together with the corrected production rate of extracellular enzymes taking into account their denaturation. Results for $P$. avidum and $P$. granulosum are summarized in the text.

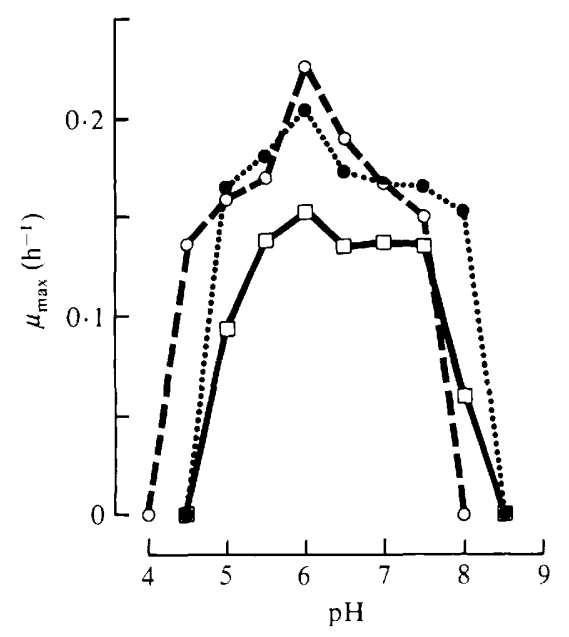

Fig. 1



Fig. 2

Fig. 1. Effect of $\mathrm{pH}$ on the maximum specific growth rate of $P$. acnes $(O), P$. aridum $(\bigcirc)$ and $P$. granulosum ( $\square$ ).

Fig. 2. Effect of $\mathrm{pH}$ on biomass production at $0.33 \mu_{\text {max }}$ of $P$. acnes (O), P. avidum (O) and P. granulosum $(\square)$. The bars represent $95 \%$ confidence limits about the mean. 


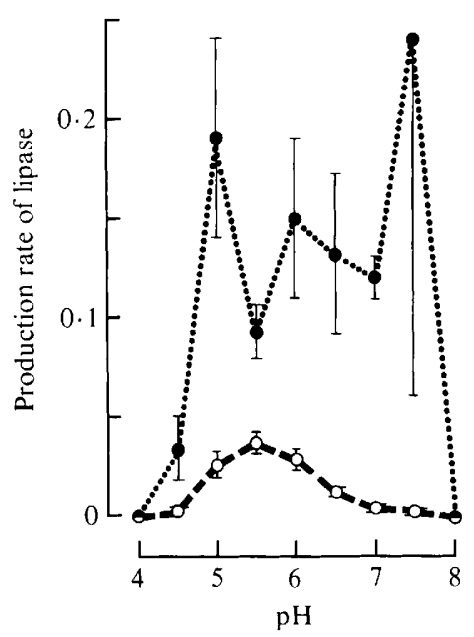

Fig. 3

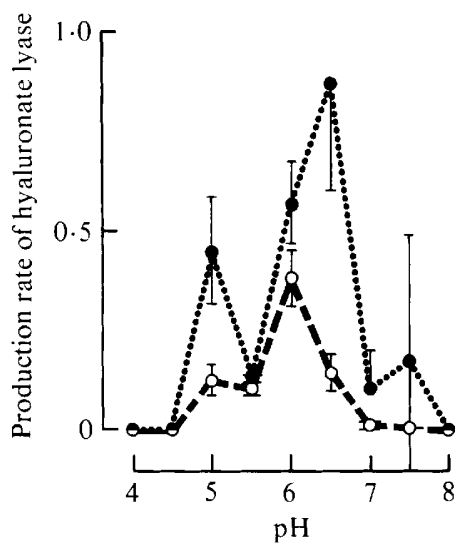

Fig. 4

Fig. 3. Effect of $\mathrm{pH}$ on the production rate of lipase at $0.33 \mu_{\max }$ by $P$. acnes, uncorrected $(O)$ and corrected ( ) for enzyme denaturation. Lipase production rate is expressed as $\mu$ mol oleic acid released $\mathrm{h}^{-1}$ (mg dry wt cells $)^{-1} \mathrm{~h}^{-1}$. The bars represent $95 \%$ confidence limits about the mean.

Fig. 4. Effect of $\mathrm{pH}$ on the production rate of hyaluronate lyase at $0.33 \mu_{\max }$ by $P$. acnes, uncorrected (O) and corrected (O) for enzyme denaturation. Hyaluronate lyase production rate is expressed as $\mu$ mol $\mathrm{N}$-acetylglucosamine released $\mathrm{h}^{-1}(\mathrm{mg} \text { dry wt cells) })^{-1} \mathrm{~h}^{-1}$. The bars represent $95 \%$ confidence limits about the mean.

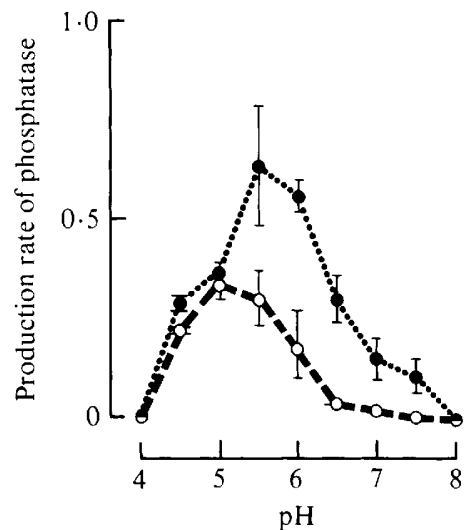

Fig. 5



Fig. 6

Fig. 5. Effect of $\mathrm{pH}$ on the production rate of phosphatase at $0.33 \mu_{\max }$ by $P$. acnes, uncorrected $(O)$ and corrected ( ) for enzyme denaturation. Phosphatase rate is expressed as $\mu \mathrm{mol} p$-nitrophenol released $\mathrm{h}^{-1}$ (mg dry wt cells) $)^{-1} \mathrm{~h}^{-1}$. The bars represent $95 \%$ confidence limits about the mean.

Fig. 6. Effect of $\mathrm{pH}$ on the production rate of proteinase activity at $0.33 \mu_{\max }$ by $P$. acnes $(O)$ and $P$. aridum (O). Production rate of proteinase activity is expressed as units $\mathrm{h}^{-1}\left(\mathrm{mg}\right.$ dry wt cells) ${ }^{-1} \mathrm{~h}^{-1}$. The bars represent $95 \%$ confidence limits about the mean.

The inighest production rate of lipase by the three species of bacteria was at $\mathrm{pH} 5.5$ with production occurring over a narrow range pH 5.0 to 6.5 for $P$. acnes (Fig. 3). Similar results were obtained for $P$. avidum and $P$. granulosum (data not shown). However, after allowance for enzyme denaturation, the corrected production rate varied little for $P$. acnes between culture $\mathrm{pH}$ values 5.0 to 7.5 (Fig. 3). Maximum corrected production rates occurred at $\mathrm{pH} 6.5$ for $P$. avidum 
and $\mathrm{pH} 5 \cdot 5$ for $P$. granulosum with a range of $\mathrm{pH} 5 \cdot 0$ to $7 \cdot 5$. Over the range tested, $P$. granulosum was capable of most lipase production, three times that of $P$. acnes.

Propionibacterium acnes and $P$. granulosum produced extracellular hyaluronate lyase. The highest production of this enzyme was at $\mathrm{pH} 6.0$ for $P$. acnes (Fig. 4) and $\mathrm{pH} 6.0$ to 7.0 for $P$. granulosum. Production occurred at $\mathrm{pH}$ values from 5.0 to 6.5 for $P$. acnes and 5.0 to 7.5 for $P$. granulosum. The corrected production rate optimum was $\mathrm{pH} 7 \cdot 0$ for $P$. granulosum and two optima were obtained for $P$. acnes, $\mathrm{pH} \mathrm{5.0}$ and 6.5. The range of $\mathrm{pH}$ for corrected production rate was 5.0 to 7.5 for both species. Production of hyaluronate lyase was greater by $P$. acnes at all $\mathrm{pH}$ values apart from $\mathrm{pH} 7 \cdot 0$, when the corrected production rate by $P$. granulosum exceeded that of $P$. acnes.

Extracellular phosphatase was detected only in P. acnes cultures (Fig. 5). The highest production was at $\mathrm{pH} 5.0$ to 5.5 and the range of production was $\mathrm{pH} 4.5$ to 6.0 ; very little enzyme was found in cultures maintained above $\mathrm{pH} 6.5$. The optimum for corrected production rate was $\mathrm{pH} 5.5$ and the range was $\mathrm{pH} 4.5$ to 7.5 .

Extracellular proteinase activity was shown in P. acnes and $P$. avidum cultures (Fig. 6). In both species, this activity was stable and the production occurred between $\mathrm{pH} 4.5$ to 7.5 for $P$. acnes and $\mathrm{pH} 5.0$ to 7.5 for $P$. avidum. The highest production rate for $P$. acnes was over a $\mathrm{pH}$ range of 5.0 to 6.5 and, for $P$. avidum, 6.0 to 7.0 .

Apart from the hyaluronate lyase of $P$. acnes, all the enzymes were produced over the entire $\mathrm{pH}$ growth range of the bacteria. Propionibacterium acnes grew between $\mathrm{pH} 4.5$ to $7 \cdot 5$, but the hyaluronate lyase was not detected at $\mathrm{pH} 4.5$.

\section{DISCUSSION}

Apart from the $\mu_{\max }$ determination, all experiments were performed at $0.33 \mu_{\max }$ for the particular $\mathrm{pH}$ maintained in the culture. This enabled comparison of the three species. However, strict comparison cannot be made between $P$. granulosum and the other two species because it was essential to include $0.2 \%(\mathrm{w} / \mathrm{v})$ glucose in the medium for $P$. granulosum (Greenman et al., 1981).

All statements concerning the ranges and optimum $\mathrm{pH}$ values for a particular species must be viewed in the light of the experiments carried out at $0.5 \mathrm{pH}$ unit increments. Propionibacterium acnes grew at $\mathrm{pH} 4.5$ and not at $\mathrm{pH} 4.0$. However, it is not possible to calculate at which $\mathrm{pH}$ between 4.5 and 4.0 growth is stopped.

It should be noted that $\mu_{\max }$ values were obtained for $P$. avidum and $P$. granulosum at $\mathrm{pH} 8.0$ by the wash-out method (Table 1) and yet at $0.33 \mu_{\max }$, values of zero biomass production are given at pH 8.0 (Fig. 2). At $0.33 \mu_{\max }$, the cultures of $P$. avidum and $P$. granulosum gradually decreased in biomass over an extended period of time $(48$ to $60 \mathrm{~h})$ and it was concluded that the cultures were not in steady states. This inability of the cultures to maintain biomass at $0.33 \mu_{\max }$ cannot be explained adequately. It might be explained by minor oscillations in the $\mathrm{pH}$ of the culture near the limiting $\mathrm{pH}$ for growth. It should be noted that the $\mathrm{pH}$ control is accurate at $\pm 0.1 \mathrm{pH}$ unit and the experiment spans a much greater time than the wash-out study for $\mu_{\max }$ when there is less chance of $\mathrm{pH}$ fluctuation in a short time.

Previous investigations have shown that the three species produce different combinations of extracellular enzymes (Holland et al., 1979; Greenman et al., 1981) and that $P$. granulosum requires a sugar carbon source in a tryptone-based medium, whilst the other two species do not (Holland et al., 1979; Greenman et al., 1981). Another difference of $P$. granulosum compared with $P$. acnes and $P$. avidum has been demonstrated in this study. Maximum biomass production in the experimental medium occurs at $\mathrm{pH} 6.0$ with $P$. acnes and $P$. avidum, with low production at $\mathrm{pH} 7.0$ and 7.5 . In contrast, $P$. granulosum biomass production is highest at $\mathrm{pH} 7.0$ and 7.5 . Differences also occur with extracellular enzyme production.

For all the extracellular enzymes studied, the $\mathrm{pH}$ affects the production rate. In addition, apart from the proteinase activities of $P$. acnes and $P$. avidum, the enzymic activity is negatively modulated by the effect of $\mathrm{pH}$ on the stability of the enzyme. This reduces the quantity of active enzyme a vailable and the $\mathrm{pH}$ range at which activity appears. For $P$. acnes the 
production of active enzyme is limited to below $\mathrm{pH} 6.5$ with maximum active enzyme production at $\mathrm{pH} 5.0$ for phosphatase, $\mathrm{pH} 5.5$ for lipase and $\mathrm{pH} 6.0$ for hyaluronate lyase. Propionibacterium avidum lipase production is similar to $P$. acnes and about six times greater. Propionibacterium granulosum extracellular lipase and hyaluronate lyase production differs from $P$. acnes enzyme production is that it occurs above $\mathrm{pH} 6.5$ and maximum production of active hyaluronate lyase is greatest at $\mathrm{pH} 7 \cdot 0$.

The proteinase activity produced by $P$. acnes and $P$. avidum is stable over the $\mathrm{pH}$ range tested and, of all the enzymes studied, is produced over the widest $\mathrm{pH}$ range. This might be explained by more than one proteinase being produced over different $\mathrm{pH}$ ranges.

It is tempting to extrapolate from these laboratory acquired results to predictions and explanations of the microbial ecology of human skin. There are inherent difficulties in such extrapolation; not the least is that only one environmental variable has been examined namely, $\mathrm{pH}$. However, the results suggest that $\mathrm{pH}$ could be one of the main factors in maintaining $P$. acnes as the most common species of Propionibacterium on the sebaceous follicle-rich areas of human skin. McGinley et al. (1978) showed that, of the three species, P. acnes had the highest frequency of isolation and population density on these skin sites, and the skin $\mathrm{pH}$ is acidic (Noble, 1968) - values ranging from pH 4.0 to 6.8 (mean 5.26) in adults were reported by Holland \& Cunliffe (1982) and means ranging from $\mathrm{pH} 4 \cdot 6$ to $5 \cdot 1$ by Abe et al. (1980). The ability of $P$. acnes to grow at a lower $\mathrm{pH}$ than $P$. granulosum, its relatively high $\mu_{\max }$ at the lower $\mathrm{pH}$ limit for growth, its extracellular enzyme production and stability, which is greatest at lower $\mathrm{pH}$ values, all suggest that $P$. acnes is well adapted to the $\mathrm{pH}$ found on human skin.

McGinley et al. (1978) reported that $P$. granulosum was less frequently isolated from sebaceous follicle-rich areas of skin and Gloor \& Franke (1978) and Leyden et al. (1975) showed that $P$. granulosum had a higher frequency of isolation from acne lesions compared with normal skin. It is possible that acne-inflamed lesions have a $\mathrm{pH}$ of or approaching $7 \cdot 4$, because of the disruption of the follicular wall and cellular infiltrate. This might give $P$. granulosum an advantage in colonizing acne lesions, because its biomass and extracellular enzyme production is greatest at pH 7.0 to 7.5. Propionibacterium avidum is limited to most moist areas of skin (McGinley et al., 1978 ) and it would be unwise to evoke arguments based on environmental $\mathrm{pH}$ to explain its limited habit.

Marples et al. (1971) showed that $P$. acnes was the major organism on human skin responsible for production of free fatty acid in skin surface lipids. The lipase of this organism hydrolyses sebum triglycerides produced by the sebaceous glands. The free fatty acid content of skin surface lipids varies from person to person [1.1 to $32 \cdot 6 \%(\mathrm{w} / \mathrm{w})($ Cotterill et al., 1971)]. This variation could be explained not only by the number of bacteria on the skin but also the active lipase production rate which can be affected by the environmental $\mathrm{pH}$. It would be predicted that a high free fatty acid content in skin surface lipids would be produced from follicles at $\mathrm{pH}$ values around 5.5. The bacterial analysis of single follicles is possible (Puhvel et al., 1975). If follicular $\mathrm{pH}$ values could be obtained then the prediction could be tested.

Some of the extracellular enzymes of the cutaneous propionibacteria may have properties in addition to their enzymic function. These may include the ability to activate the alternate complement sequence, to be antigenic, or to be chemo-attractant to phagocytic cells. These properties may play an important role in causing inflammation in acne (Holland et al., 1981). The different stabilities of these enzymes at different $\mathrm{pH}$ values may only be with respect to their enzymic (catalytic) function; the molecules may still retain other biological properties. The presence of 'denatured' enzyme becomes apparent after applying the correction formula to the measured rates of enzyme production. In every case, the corrected production rate is significantly higher (up to sixfold) than the measured rate.

This relatively high amount of inactive enzyme may be of importance in the pathogenesis of acne if its production occurs in vivo and if it does possess other biological properties.

Until the effects of the other enzymes on the follicular environment are known there can be no speculation about the effects that $\mathrm{pH}$ will have on these enzymes in vivo.

The authors wish to acknowledge the financial support of the Medical Research Council throughout this study. 


\section{REFERENCES}

Abe, T., Mayuzumi, J., KiKuchi, N. \& AraI, S. (1980) Seasonal variations in skin temperature, skin $\mathrm{pH}$, evaporative water loss and skin surface lipid values on human skin. Chemical and Pharmaceutical Bulletin 28, 387-392.

Cotterill, J. A., Cunliffe, W. J. \& Williamson, B. (1971). The effect of trimethoprin-sulphomethoxazole on sebum excretion rate and biochemistry in acne vulgaris. British Journal of Dermatology $\mathbf{8 5}$ $130-133$

Eaves, G., Greenman, J. \& Holland, K. T. (1979). Decay rates of exocellular enzymes produced by bacteria - correction of production rates in chemostat cultures. FEMS Microbiology Letters 6, 333-336.

Evans, C. G. T. (1976). The concept of relative growth rate. In Continuous Culture 6: Applications and New Fields, pp. 346-348. Edited by A. C. R. Dean, D. C. Ellwood, C. G. T. Evans \& J. Melling. Chichester: Ellis Horwood.

GLOOR, M. \& FRANKe, M. (1978). On the propionibacteria in the pilosebaceous ducts of uninvolved skin of acne patients. Archives of Dermatological Research 262, 125-129.

Greenman, J., Holland, K. T. \& Cunliffe, W. J. (1981). Effects of glucose concentration on biomass, maximum specific growth rate and extracellular enzyme production by three species of cutaneous propionibacteria grown in continuous culture. Jour nal of General Microbiology 127, 371-376.

Hassing, G. S. (1971). Partial purification and some properties of lipase from Corynebacterium acnes. Biochemica et biophysica acta 242, 381-394.

Herbert, D. (1976). Expression of bacterial growth equations in dimensionless form. In Continuous Culture 6: Applications and New Fields, pp. 353-356. Edited by A. C. R. Dean, D. C. Ellwood, C. G. T. Evans \& J. Melling. Chichester: Ellis Horwood.

Holland, D. B. \& Cunliffe, W. J. (1982). Skin surface and comedome $\mathrm{pH}$. Journal of Investigative Dermatology (in the Press).

Holland, K. T., Cunliffe, W. J. \& Roberts, C. D. (1978). The role of bacteria in acne - a new approach. Clinical and Experimental Dermatology 3, 253-257.

Holland, K. T., Greenman, J. \& Cunliffe, W. J. (1979). Growth of Propionibacterium acnes on synthetic medium: growth yields and exoenzyme production. Journal of Applied Bacteriology 47, 383-394.

Holland, K. T., Ingham, E. \& Cunliffe, W. J. (1981). The microbiology of acne. Journal of Applied Bacteriology 51, 195-215.

Ingham, E., Holland, K. T., Gowland, G. \& Cunliffe, W. J. (1979). Purification and partial characterization of hyaluronate lyase (EC 4.2.2.1) from Propionibacterium acnes. Journal of General Microbiology 115, 411-418.
Ingham, E., Holland, K. T., Gowland, G. \& Cunliffe, W. J. (1980). Purification and partial characterization of an acid phosphatase (EC 3.1.3.2) produced by Propionibacterium acnes. Journal of General Microbiology 118, 59-65.

InGHaM, E., Holland, K. T., Gowland, G. \& Cunliffe, W. J. (1981). Partial purification and characterisation of lipase (EC 3.1.1.3) from Propionibacterium acnes. Journal of General Microbiology 124, 393-401.

Kellum, R. E., Strangfeld, K. \& Ray, L. F. (1970). Acne vulgaris. Studies in pathogenesis: triglyceride hydrolysis by Corynebacterium acnes in vitro. Archives of Dermatology 101, 41-47.

Leyden, J. J., MCGinley, K. J., Mills, O. H. \& Kligman, A. M. (1975). Propionibacterium levels in patients with and without acne vulgaris. Journal of Investigative Dermatology 65, 382-384.

MARPles, R. R. \& MCGinley, K. J. (1974). Corynebacterium acnes and other anaerobic diphtheroids from human skin. Journal of Medical Microbiology 7, 349357.

Marples, R. R., Downing, D. T. \& Kligman, A. M. (1971). Control of free fatty acids in human surface lipids by Corynebacterium acnes. Journal of Investigative Dermatology 56, 127-131.

Marples, R. R., McGinley, K. J. \& Mills, O. H. (1973). Microbiology of comedomes in acne vulgaris. Journal of Investigative Dermatology 60, 80-83.

MCGinley, K. J., Webster, G. F. \& Leyden, J. J. (1978). Regional variations of cutaneous propionibacteria. Applied and Environmental Microbiology 35, 62-66.

Millett, J. (1970). Characterisation of proteinases excreted by Bacillus subtilis Marburg strain during sporulation. Journal of Applied Bacteriology 33, 207219

NOBLE, W. C. (1968). Observations on the surface flora of the skin and on the skin pH. British Journal of Dermatology 80, 279-281.

Puhvel, S. M. \& Reisner, R. M. (1972). The production of hyaluronidase (hyaluronate lyase) by Corynebacterium acnes. Journal of Investigative Dermatology 58, 66-70.

Puhvel, S. M., Reisner, R. M. \& Amirian, D. A. (1975). Quantification of bacteria in isolated pilosebaceous follicles in normal skin. Journal of Investigative Dermatology 65, 525-531.

TEMPEST, D. W. (1976). The concept of 'relative' growth rate: its theoretical basis and practical application. In Continuous Culture 6: Applications and New Fields, pp. 349-352. Edited by A. C. R. Dean, D. C. Ellwood, C. G. T. Evans \& J. Melling, Chichester: Ellis Horwood. 